\title{
The philosophical and psychological aspects of a phenomenon of leadership in culture
}

\author{
Irina Khmyrova-Pruel \\ Institute of Philosophy \\ Saint Petersburg State University \\ Mendeleevsky line of 5, 199 034, Saint Petersburg \\ Russian Federation \\ e-mail: hmy-p@list.ru \\ Alexander Koloskov \\ Institute of Philosophy \\ Saint Petersburg State University \\ Mendeleevsky line of 5, 199 034, Saint Petersburg \\ Russian Federation \\ e-mail: alexnikkoloskov@yandex.ru
}

\begin{abstract}
This paper is devoted to study of the ontological and existential bases of a phenomenon of leadership in (mostly) Russian culture. The mere existence of the word "leadership" in concept language demonstrates the special status of this phenomenon in culture. Leadership is considered both in the context of change of art paradigms, and in personal aspect, at the level of the subject of culture. The research of this phenomenon is connected with studying the features of overcoming tradition, "fear of influence", and in the same time impossibility of an exit for a framework of sign borders, as well as the need to be "understood". On the other hand, at the level of the subject, the problem of "egoism", overcoming (or "forming") limits of moral autonomy, determination of specifics of "action", a reflection over "abilities" are shaped.

The paper analyzes the multi-level specifics of leadership in culture: both at the social level created by ideas of success (based on idea of progress and the subsequent transformations of this representation in post-industrial society, or a "consumer society"), and also at the metaphysical level connected with existential and valuable problems, as well as problems of ontological bases of culture and the person. We make an attempt to comprehend the ratio of leadership and of ways of its "recognition" in modern culture. Finally, we draw conclusions about features of axiological models in the present and specifics of their reflection.
\end{abstract}

\section{Introduction}

The problem of "leadership" in a modern scientific paradigm is related to the researches focused on practical application, such as psychology, sociology, political science, and so forth. Philosophical approach to the marked problem - assuming orientation on integrity of studying - allows to comprehend both an "ontological", and existential basis of a phenomenon of leadership, focuses on axiological models of modern culture.

Fixing on a concept "leadership" in a scientific discourse and practicians who create models of modern life, wide connective fields of this concept, and finding of this status in the language demonstrate to representativeness of this phenomenon in the history of a thought, especially in the period of a modernist style which is, according to Habermas (1985), remains an incomplete project. Specifics of perception of history in the modern (a linearity, progressiveness, the movement "from" and "to"), a reference point on discourse fixing of realities of life, the belief in science and progress, all become the basis for forming of modern spheres of concepts in which special place is taken by a concept "leadership".

Application of a concept of "leadership" in understanding of the sphere of culture can be extremely vast: from a research phenomenon of the creative person before studying of a phenomenon of change of art paradigms. Thence, for example, polemic about the literary directions in the Russian literature and so-called phenomena of the "transitional" periods are indicative. At the end of the $20^{\text {th }}$ century, the famous researcher of the Russian literature of the $18^{\text {th }}$ century Zapadov (1907-1998) noted that in definition of a number of the art directions researchers meet difficulties of establishment of borders and definitions per se (Zapadov 1995). Stylistic, genre and other characteristics from poetics not always satisfy the inquiries of the researchers and cannot define feature of a number of works. Today, it is quite possible to raise a question of efficiency of historical and cultural approach to reference of works to this or that direction/method without an ontological basis of creativity of the specific author. No doubt, reference of texts of Radishchev both to sentimentalism, and to "early Russian realism" are quite lawful taking into account need of the artist to show own "I" and desire to be the witness heard in that cultural 
environment which is created by tradition and stays in a certain tradition. The same is also related to a situation of definition of "pre-romanticism". Zapadov (1995) noted that "classicism of the 18th century - both educational classicism of the French literature, and the Russian classicism at all its stages, starting with Kantemir, proceed not from Descartes (to enough remember extremely negative reviews of Cartesian philosophy of such leading classicists of Russia as Lomonosov and Sumarokov), and from Locke", but to the philosophical ideas of the last, according to the author, there go back the ideas of "coryphaeuses of sentimentalism and pre-romanticism". The idea about Descartes's role needs special commenting, so we will only note that the fact of a possibility of creation of the standard poetics so widespread at that time, demonstrates value of the ideas of Descartes in selfunderstanding of the European culture lasting to this day. The impossibility to connect the art direction with any one philosophical concept causes need of refocusing of a view of a problem: significant is not what from philosophical thought the author leans on and as he was rethinking these ideas, acquires and realizes in creativity. Often it turns out that the author and his creativity "oppose" to the conclusion in a framework, them established (and sometimes and "declared in poetics, esthetic treatises, "manifestos" and so forth). And in that case "preromanticism" can be considered as a special cultural situation in which intensions of overcoming tradition ("leadership"), statements new and at the same time, a certain communication with "old", clear and accepted are developed. On the one hand, humanitarian knowledge since the $20^{\text {th }}$ century strives for "scientific character", accuracy and formalization of proofs and conclusions. It causes also rational paradigms of "history" of arts, attempt of hierarchy and structure during its creation. And in this context "leadership" is understood as a certain movement on a way of expansion of art spaces, enrichments of meanings. On the other hand, the nature of art creativity and a sacrament of the creative act switch the register of the analysis to a perspective existential, to processes intra personal, on intension of the author to overcome tradition and impossibility of a complete separation with it. Not casually, addressing a research to the fundamental and having long and thorough story of studying problem of "realism", Kotelnikov (2010) (the Russian literary critic and the philologist) builds the line of the analysis on comparison and studying of interference of the main vectors in philosophy and literature: realism and idealism (Kotelnikov 2010). It is necessary to agree with the author that in the 19th century: "events of formations of meanings happened in the movement from empirical knowledge to ideal entities and from them - to critical understanding of reality in its attitudes towards these entities" (Kotelnikov 2010). Culture having literature in the center with a large number of fundamental author's discourses to some extent stabilized a leadership phenomenon, having bared its existential basis, having actually made this basis main "trump" in "fight for minds and hearts" of public. And kind of further "esthetic declarations" were made out there is "primary act of the relation to the world is a recognition of life as unconditional reality, recognition of a ontological order as approving real in eternity. But then human freedom chooses the ways, with this world order dispersing and then there is a rejection real, its denial in the private empirical phenomena and in its "ontological bases" (Kotelnikov 2010). Therefore, inheriting criticism of the 19th century, representatives of vanguard, often outright declaring the leadership in art, art practicians showed deep communication with tradition, impossibility of a gap with it. For example, language experiments of futurists approved laws of language, and reflections about a modern language of painting of Kandinsky were directed to overcoming stamps and canons for the purpose of return to original - spiritual - in art. Alfonsov (1931 - 2011), the Soviet and Russian literary critic) noted that, for example, David Burliuk who headed the attacks of futurists to classics: "itself in the verses actively mastered the Russian poetic tradition from poets of the 18th century to K. Sluchevsky, V. Bryusov and A. Bely, not to mention the new French" (Alfonsov 1999). And besides, as well as in the examples given above, researchers face need of specification of contents and borders of concepts Avangard, "futurism" and so forth: "sense, apparently, not in expanding futurism ... It is more important "to adjust" the futurism relations with others, "not futuristic", the directions of art ... The concept Avangard significantly is also still irreplaceable in relation to painting ... In relation to literature this concept already raises a number of doubts. Limits of vanguard become more difficult to be defined, does not act, but the problem is muffled over time, flimsy are concrete estimates" (Alfonsov 1999). Developing this thought of the author, it is possible to add that among the most effective processes of change of art paradigms for understanding approaches to studying of author's discourses in which intensions of "leadership" individually are implemented are. The research of this phenomenon has to be connected with studying of features of overcoming tradition, "fear of influence" and at the same time impossibility of an exit for a framework of sign borders, the need to remain "understood". On the other hand, at the level of the subject the problem of "egoism", overcoming (or formings) limits of moral autonomy, determination of specifics of "action", a reflection over "abilities" is formed.

\section{Leadership in culture}

Leadership in culture can be considered at several levels: a social level, caused by ideas of success and success (based on idea of progress and the subsequent transformations of this representation in post-industrial society, "consumer society") and also at the metaphysical level connected with the existential problems, as well as valuable problems of ontological bases of culture and the person. 
Transitional eras in cultural and historical process are often characterized by instability. These periods, as a rule, are followed by crises, emergence and escalation of the risks provoking the destructive phenomena in culture, transformations of outlook of society in general, social and cultural shifts, discrepancy of art tendencies and at the same time - active innovative search in all spheres of activity. From this point of view the keen interest in transitional eras which is observed in a philosophical and historical thought in the last decades is of natural.

The phenomenon of leadership is object of studying of many scientific directions of humanitarian knowledge within which are intensively investigated and analyzed its most various aspects. Social and psychological, social and political approaches to a research of problems of leadership are most widespread. Besides, within this problem, outside attention of scientific community still there is a number of the directions of the analysis expecting the hour to which number, undoubtedly, philosophical belongs. And philosophical view of the phenomena and processes is priority in today's situation as it assumes concentration on studying of valuable contents human, and, therefore, the activity as a leadership dominant transforming culture.

"The leader in culture and art" - a concept which has no full scientific justification. The problem designated by this concept is confirmed first of all by practice of creation of culture during an era of scientific and technical progress, especially - in the conditions of totalitarian public systems.

The theatrical critic of the beginning of the $20^{\text {th }}$ century Kugel (1864-1928) noticed: "not the power and coercion, not violence and threats, but love and self-restriction for beauty the harmony of archaic existence keeps. Therefore, in general, any power does much more harm, than advantage" (Kugel 1923).

Culture in general and all collective arts in particular in a century of totalitarianism, automation and mechanization, integration and modernization practically of all spheres of human activity paradoxically isolates in itself each personality. And especially that which on certain circumstances is above collective it can be the theatrical or cinema director, the conductor, the architect; and that personality who is obliged to connect, merge with others it is the performer - the musician, the actor.

\section{Leadership concepts in psychology}

In psychology, there are considerable practices connected with the leader's phenomenon in culture in his general view, giving examples of set of the corresponding numerous qualities. Along with belief in the business (up to fanaticism), courage, commitment, determination psychologists point all these qualities to such private property as ability to show to subordinates. If it is about the identity of the leader, but not about formally appointed chief, there is no of properties which would be little significant.

The social psychology traditionally considered, for example, the leader's life on production. The era of scientific and technical progress imposed special requirements to the one who leads thousands of experts with high qualification, having isolated the manager's figure. However the system of sciences about culture does not consider such scientific position: the organization of "work" (that is creative process in general) and the organization of collective life (that is, in particular, moral atmosphere, not to mention economic problems) are not mutually excluding. All these forms of activity at the true leader are by all means interconnected. And along with function of administrative management from the leader constantly it is required to carry out, at first sight, private, and in fact, the major function - decision-making.

It is established that human groups "can differ on extent of formalization"(Hyman 1942). In "formal" group the structure is established from above, and in such group say about the leader that he possesses the recognized power. In "reference" group association of people happens, so to speak, "to liking", and the owner of sympathies becomes the leader. The concept of "reference" group which belongs to the American social psychologist Hyman, entered scientific use in the early forties traditionally makes rather broad sense used "for designation of any group to which the individual correlates the installations" (Hyman 1942). However, ideas of its standard function are dominating in a concept about "reference" group (the group, owing to compliance or discrepancy to its installations, recognizes or does not recognize an individual) and about function as comparative, "softer" in relation to the personality (when "the group serves as a standard, a starting point for comparison...") (Hyman 1942). The equal-sign between concepts of "reference" and "small" groups as only rather small number of participants (from 7 to 20 people), can fruitfully function in the original quality is almost always put. In the sphere of culture the model of reference group is the representative and correctly fixing specifics interpersonal communication in the conditions of joint (including art) creativity. Presence of the leader as structure-forming size is characteristic of small ("reference") group, as well as of any other human association.

Problem of a ratio of groups with various quantitative and qualitative characteristics and their leaders, being developed for application in scientific activity, to sport, it is practically not investigated in relation to the art sphere. Nevertheless, the art collective, regardless of its sizes, integrally exists under the laws peculiar to existence of "reference" groups. Obviously, exactly there passes the side between "theater for the audience" as Meyerhold (Vahtangov 1939) called the habitual status, and studio - association of the fans or beginning, or just friends, it is pleasant to them to be together, but which do not address fruits of the activity to general and unfamiliar public. From this it follows that in theater, cinema, musical performance - in arts collective where the interdependence of 
each personality and group in general is so high, - the value of "reference" groups is so essential. Any stage and any situation of the remote or recent past convince of it. Out of "reference" group there is no theater, film crew, orchestra; the way to "formal" group (that there is no negative quality at the strict use of the term) in culture lies through group "reference". "Directors gained for themselves authority of troupe that gave them the chance to begin to carry out the art tasks planned by theater", - Stanislavsky summed up the result of the first decade of Art theater (Stanislavsky 1958). Creation of "reference" group at the first moment of finding of the power over group "formal" - a natural and fruitful step which on production would be hardly feasible.

Experience of informal leadership in culture is natural, and the fact that many leaders at the first stages of the way to leadership set local tasks is also natural. The leader builds the relations with this, specific collective, and the benefit if over time all members of big collective become his colleagues if further formal group where it "the recognized power", he will manage to make "reference". But it already depends not only on this person, but also on the collective as "rather high social and psychological culture or optimum social and psychological climate is necessary for achievement of effect of a personal realization in collective" (Hyman 1942).

The despotism at the leader in culture is almost unacceptable. But those who persistently and skillfully lead formal groups at all individual distinctions, at a difference of art programs and tastes meet in one: it is impossible to try "to be darlings" all and always.

The director Goncharov (1918 - 2001) who for several decades belonged to number of recognized theatrical leaders and successfully headed serially three Russian theaters, every time giving their lives a necessary tone, noticed regularity: "It is impossible just to come to actors and to tell: "Let's fall in love with each other!". People unite only around concrete work" (Goncharov 1980). The leader working in culture in practice felt and precisely formulated the known provision of social psychology that "most of groups take the form after infinite tests and mistakes" as most often the general interest is "one of results of joint action" (Goncharov 1980).

According to the theory considering a set of phases of development of groups - from conflict dependence to "the coordinated validity", - the last, the steadiest and productive, is the phase reached by master creators during blossoming of their leadership. On this phase "the conflict exists, but on substantial, but not on the emotional basis;... consent is reached as a result of a rational discussion, but not on the basis of coercion to unanimity; as a result of estimation processes participants gain the best personal understanding of each other" (Shibutani 2017). Awareness of mutual need unites creative group as the leader managed to construct life, having precisely defined ways of communication of people - in this case on a professional basis - and to provide "the maximum use of opportunities and abilities of members of the group" (Shibutani 2017). However, if the leader lingers on a situation of "reference" group, then in his formal group surely there is a new leader creating the "reference" group.

Traditionally it is considered that the most difficult stage of activity of the leader - it began. The founder of the Moscow Art Theatre Stanislavsky noted special property "and a variety of the talant demanded from one person" "at the beginning" (Stanislavsky 1958) - at the time of construction of new collective. But "having constructed" theater - having created troupe, having developed the esthetics, having defined the principles of repertoire policy, - the leader continues work. At this stage misunderstanding, alienation of former adherents, disintegration of the developed organizational structure and system cultural integrity created earlier can wait for it.

In the sphere of culture at a stage of stable existence of group dissociation of the leader and the collective created by it happens more visually, than anywhere: from goings of the famous actors from theaters where their talent (from Meyerhold, from Tovstonogov), to the scandalous "section of property" between Lyubimov and a part of actors of Taganka Theatre was created.

The question concerns not only the leader who lost tolerance at the time of a gap with the collective created by it. The leader's position - pariahs is expressed by Vahtangov (1939); he addressed reproach to pupils, too quickly and fondly believed in the equality with the teacher: "It I told that all should bear light of our knowledge; it I forgave the fact that it is impossible to forgive; it I allowed to treat me, the head, as the person with whom it is possible not to reckon". How the leader who is that was loved by right, he it is frequent, owing to the psychological or esthetic reasons, turns into "the one who receives slaps in the face" (Vahtangov 1939). "Slaps in the face" from the disappointed members of the collective or from uncomprehending public, from which was undeceived or too, contrary to all external circumstances, confident in the right for leadership and in agreement of opinion of conducted.

\section{Leadership in art}

In the art sphere which developed in totalitarian society, the state steadily created on-stage performance groups and studios significantly differed: theatrical, musical, or ballet. The studio from usual theater or orchestra, chorus in Soviet period was distinguished by two types of orientation of people: on the power (in the state collective) and at each other (in studio). This two types of orientations as researchers noted a psychological situation, are various as concepts "the power and love" are various. 
Analyzing various phases of group development, experts describe what they as if observed in art, giving the chance to understand natural character of the considered cultural collisions; psychologists find it possible to operate such collisions. They describe one of phases so: "The group is happy, rallied and relaxed. The atmosphere - one of those which are "light and pleasure"... Usually is time of fun and poetry. During this period all decisions are made unanimously as everyone has to be happy" (Kugel 1923). But, by recognition of researchers, the maintenance of this stage and orientation not on business but only on personal motivations dooms her to short duration.

For the culture where individual creativity matters, as well as in general any manifestations of the personality, a special role are played by the division of leaders on two types established by psychologists in the $1920^{\text {th }}$. The principle of this division is applicable to the leading organizer of art process or to the leader keeping from everything except creativity (while he acts nevertheless in collective). "One - the researcher notes, - strive for the high social status, and only then, as leaders, feel on the place" (Spranger 1966) Such call "active", unlike others - "passive". In activity of leaders of these two types as consider, "on one pole there is purely physical power, on another - the power mediated spiritually" (Spranger 1966).

In process of development of art in totalitarian conditions, under the law of contrast, in Russia of the end of the $20^{\text {th }}$ century, the status of leaders was "passive" below, irrespective of personal characteristics became higher and higher, than leaders who remained "active". Moral, psychological loading appeared the excessive, disturbing own creative activity (e.g. the playwright Vasilyev, film directors Sokurov, Muratova, or the conductor Rozhdestvensky).

The leader in culture is obliged to love, to take the responsibility, to lead not months, but years. Psychologists established: "... those who dominate not only make decisions, but also in many cases undertake also protection of the followers" (Shibutani 2007). Therefore, the harmonious combination of desire and ability is important for the leader in culture.

The paradox is characteristic of self-realization of creative persons in culture: introverts become more often than others leaders, professor Kolominskij (1973) assumes. It would seem, the introvert painter (Van Gogh) or the introvert poet (Baudelaire) - the phenomenon quite natural. But the introvert director or the introvert conductor nearly an oxymoron. However, the phenomenon, similar to the largest Russian director Efros, is psychologically quite explainable. Obviously, the answer is here that not all introverts, and only those about whom the psychology speaks as about "stars" become leaders (see Kolominskij 1973).

\section{Conclusions}

Distinguishing the concepts "leader" and "head", it is possible to note that the head in the scientific sphere or in the sphere production can carry out the functions, without being the leader in the emotional relation. In culture (in particular, art) it is almost impossible - rather on the contrary - in order to: "achieve full use of abilities of subordinates, the head has to cause in them the corresponding response, carrying out leadership" (Krichevskij and Dubovskaya 1991).

Important aspect in recognition of "leader" and "leadership" is recognition behind them "the moral right", moral presets. Paul Ricoeur (2005) explained disappearance of "egoism" in interpretation of moral autonomy with lack of a thematization of action as practical field in which norms dominate (Ricoeur 2005). The thinker for an epistemic mode of the statements relating to the register of abilities uses the term "certificate". The standard beliefs are a weak form of theoretical knowledge while a belief mode in the statements of a look "I believe that I can" is much stronger. According to the author, the confidence which is given rise by a statement "I can", the contrast has not doubt, and suspicion which can be rejected only by new confirmation with the same epistemic contents, as the challenged confidence. In a case with a phenomenon of leadership recognition identification and recognition certificate are necessary. Self-identification - the first on this way. Feeling of internal compliance, readiness to bear responsibility, a reflection and introspection - the factors necessary for recognition. The problem "who" in definition of leader/leadership and process of its identification grows from the question "who speaks?". The speech is in a varying degree informative not only in itself, but also confirms the subject, it giving rise / saying owing to what the speech is of particular importance in the course of recognition of the leader. And, of course, moral and ethical installations, the principles of the leader, especially in modern culture with the mobile axiological bases (according to Bauman, "the fluid present") (Bauman 2001), perceived not only on rational, but also at the sensual level, based on esthetic sense have special value.

Identification of parameters of the personality in culture has empirical character; at the same time there is no system of special preparation and sociocultural adaptation of leaders in culture. Thereof, this cultural phenomenon is unique and non-reproducible. 


\section{References}

Alfonsov V, Poeziya russkogo futurisma [Poetry of Russian futurism], 1st edn. (Akademicheskij proekt: SPb, 1999), $752 \mathrm{p}$.

Arefeva E, Denisov Y, Sovremennaya zarubezhnaya social'naya psihologiya [Contemporary foreign psychology], 1st edn. (MGU: M, 1984), 255 p.

Bauman Z, The Individualized Society, $2^{\text {nd }}$ edn. (Wiley: Hoboken, 2001), 272 p.

Filippova A, Teoriya obshchestva: fundamental'nye problem [Theory of the society: fundamental problems], 1st edn. (Kanon press-C: M, 1999), 416 p.

Goncharov A, Rezhissyorskie tetradi [Director's diaries], $1^{\text {st }}$ edn. (GITIS: M, 1980), 142 p.

Habermas J, Philosophical-political profiles, $2^{\text {nd }}$ edn. (MIT Press: Cambridge, 1985), 213 p.

Hyman H, The psychology of status, $1^{\text {st }}$ edn. (Archives of Psychology: New York, 1942), 94 p.

Kolominskij Y, Chelovek sredi lyudej [A man among people], 1st edn. (Molodaya gvardiya: M, 1973), 240 p.

Kotelnikov V, Chto est' istina? (Literaturnye versii kriticheskogo idealizma) [What is reality? (Literary version of critical realism), 1st edn. (Pushkinskij Dom: SPb, 2010), 672 p.

Krichevskij R, Dubovskaya R, Psihologiya maloj gruppy [Psychology of a small group], 1st edn. (MGU: M, 1991), $205 \mathrm{p}$.

Kugel A, Utverzhdenie teatra [Foundation of theatre], 1st edn. (Teatr i iskusstvo: Sankt-Peterburg, 1923), 208 p.

Kunc G, O'Donnel S, Sistemnyj analiz upravlencheskih funkcij [System analysis of management functions], $1^{\text {st }}$ edn. (Progress: M, 1982), 198 p.

Mangejm K, Problema intelligencii: Issledovaniya ee roli v proshlom i nastoyashchem [Problems of intelligentsia: researching its role in the past and present], 1st edn. (Mysl: M, 1993), $250 \mathrm{p}$.

Ricoeur P, The Course of Recognition, $1^{\text {st }}$ edn. (Harvard University Press: Cambridge, 2005), 297 p.

Shibutani T, Society and Personality: The Interactionist Approach to Social Psychology (Social Science Classics Series), 3d edn. (Routledge: New York, 2017), 648 p.

Simmel G, Simmel on Culture: Selected Writings, $2^{\text {nd }}$ edn. (SAGE Publications: Thousand Oaks, 1997), 302 p.

Spranger E, Types of Men: The Psychology and Ethics of Personality, $2^{\text {nd }}$ edn. (Johnson Reprint: New York, 1966), $402 \mathrm{p}$.

Stanislavskij K, Sobranie sochinenij [Collection of works], 1st edn. (Iskusstvo: M, 1958), 200 p.

Vahtangov E, Zapiski. Pis'ma. Stat'I [Notes, letters, and articles], 1st edn. (Iskusstvo: M, 1939), 405 p.

Zapadov V, Literaturnye napravleniya $v$ russkoj literature 18 veka [Literary genres in the Russian literature of the $18^{\text {th }}$ century], 1st edn. (IMA-press: SPb, 1995), $180 \mathrm{p}$. 